\title{
The Changes on Scale-Up Agriculture Business Transformation Process in Rural Area
}

\author{
Devi Maulida Rahmah*, Fahmi Rizal*, and S.rosalinda** \\ *Lecturers of Agricultural Industry Technology Department, Universitas Padjadjaran \\ ** Lecturer of Biosystem engineering Departement, Universitas Padjadjaran \\ devi.maulida.rahmah@unpad.ac.id
}

\begin{abstract}
This study aims to identify the changes in Scale-up Business Transformation Process in PT Malabar Kopi Indonesia. PT Malabar Kopi Indonesia is the largest coffee processing business unit in West Java, established in 2005. Initially, this coffee business was categorized to household-scale coffee processing business (Small enterprise scale) and currently the company has become a coffee processing business unit that exports coffee to various countries. The development of this business is eligible to be identify the business changes occured. This study was conducted through field observation and deep interview. The data were analyzed through historical analysis. Through historical analysis approach, all details in innovation process conducted by PT Malabar Kopi will be explained.

The results show that the changes on scale-up transformation process is divided into 4 terms, namely product changes, process changes, technological changes, and organizational changes. Product changes occurred four times along the business established. Initially, the company produced cherry bean as the main product on 2005. Changes occurred due to the company's desire to meet the market demand and increase value-added of products on 2009, when started producing green bean and roasted bean. In 2014 they started producing instant coffee and increased the production quantity of Green bean and roasted bean to meet the international market through exporting activity. The Process changes occurred 4 times, it closely related to the product changes. The changes from wet process to dry process occurred on 20014 due to the company target which focused to export market. The change also occurred on 2017 when the dry process moved to the natural process due to the domestic market become the targeted on this year. Shortly, the process chanced occurred based on the market will be targeted. The Technological changes helped the company to get the good quality and quantity of product. In term of the organizational changes, it become the basic change to get the market expansion. Especially in 2014, in the initially formed of company that categorized into small and medium scale enterprises moved to large scale enterprise. Marked by the transformation into a limited liability company (PT). The changes that occur have an impact on the networking opportunity and develop a broader business. Here is the historical change of business form.
\end{abstract}

Key words: Agricultural Business, Business Innovation 


\section{Introduction}

\section{Background}

In Indonesia, agriculture sector still plays important role in national economy since its role as the supplier of food for the population, raw materials for the agricultural industry, the income source for millions of farmers throughout Indonesia, and the source of foreign exchange earners after oil and gas sector. In broad terms, agricultural context includes several sub-sectors such as plantation, forestry, livestock, and fishery. One of the subsectors given more attention by the government is plantation sector (Ministry of Republic Indonesia, 2009).

Coffee is one of plantation commodities included in the category of Strategic Commodities in Indonesia. As the third largest coffee producing country in the world, Indonesia is able to produce at least 748 thousand tons or $6.6 \%$ of world coffee production in 2012. Moreover, the growth of consumption of processed coffee products in this country increases by an average of $7.5 \%$ per year. This increase of coffee demand in terms of both domestic and international markets has become an opportunity for coffee business in the future.

The development of coffee business in Indonesia arises within the last 15 years, indicated by the increase of coffee production, the amount of coffee exports, and the value of investments. In 2010, the production of coffee reached $554,574.00$ tons, export volume 340,887 tons / year with investment value 326.256 million USD while in 2014, the production reached 685,089 tons, volume exports 534,023 Ton / year with investment 1,252,523 million USD. Thus, it shows that since the past 15 years, the production, export volume, and investment value have been considerably potential. In addition, the increase in investment value is very high because the coffee price is considered increasing relatively high as well. Based on data released by Indonesian coffee association, it is noted that the price of Indonesian coffee market in the world is classified at high rate with Arabica coffee selling value 134.3 USD per kilogram and Robusta coffee 1922.4 USD per kilogram in 2017. Therefore, it can be said that Indonesia is considerably potential to obtain financial benefits from coffee agroindustry

The development of coffee business is inseparable from main actors within each sub-sector of coffee agro-industry, i.e. farmers, farmer groups, and coffee processing business actors. Accordingly, the number of small and medium scale coffee business actors is increasing from year to year, indicated by the increase of land area, production, and export volume. In this case, parties also considered important in the chain of coffee industry are farmers and coffee farmer groups (FG). It has been recorded that the presence of farmers groups in Indonesia in 2017 reached 553,289 throughout Indonesia. Of the 553,289 farmer groups, about 50,966 farmer groups of plantation commodities were recorded, including groups of coffee farmers.

Furthermore, $100 \%$ of cherry bean production is produced in rural areas. The majority of coffee processing businesses are also located in rural areas. Therefore, these strategic commodities should have a positive impact on the socio-economic conditions of rural areas' people. Pangalengan sub-district is a sub-district producing large quantities of coffee. The 
area of coffee planted threre is $780.3 \mathrm{Ha}$. With a total of coffee produced reaches 7,431,345 Ton / Year. Every village in Pangalengan has The Association of coffee Farmer groups under sub-district farmer group authotization. In Pangalengan, there are also many coffee processing businesses, three of which are known to carry out export activities routinely every year. This complete subsystem of coffee agro-industry from upstream to downstream in this region makes Pangalengan a coffee-producing area and the largest coffee exporter in West Java.

PT Malabar Kopi Indonesia, is the largest coffee processing business unit in West Java. Established in 2005. Initially, this coffee business was categorized to household-scale coffee processing business (Small enterprise scale), Today, the company has become a coffee processing business unit that exports coffee to various countries. The development of this business is categorized as the limited liability company (in Bahasa: Perseroan Terbatas), to be eligible to identify the innovation processes occured. According to Mason, Bishop and Robinson (2009), innovations have a strong correlation with business progress. The results of his research show that the more companies create innovations, the faster the companies grow. This research is intended to identify the innovation process in PT Malabar Kopi Indonesia which has progressed through a growing number of business indicators.

\section{Research purposes}

The purpose of this research is to identify the business innovation process conducted by PT Malabar. The process of innovation observed is innovation in products, processes, technologies, and organizations. The benefit of this study is expected to be a reference for more innovation process that may be done by similar businesses with similar system characteristics, especially in agro processing business unit in rural areas. Furthermore, the advantage of this study results is as a reference for the determination of the appropriate process approach in developing coffee processing business in the rural areas.

\section{Research methods}

This research is included in explorative category, since researchers observe the object directly in the field and conduct a deep interview to the related stakeholder. The data are presented through historical analysis approach. The historical analysis will describe the sequences of the process clearly, particularly, in presenting the innovation processes as the basis for process, technology and organizational changes that occur in business unit.

\section{Result and Discussion}

The innovation process in PT Malabar Kopi Indonesia can be identified by several processes, as follows:

\section{Product Changes}

The main key of PT Malabar Kopi Indonesia to run its business is by adhering the principle "to meet the needs of market demand". The market has diverse in preferences. Market demand will continue to grow as technology advances. 
The table below shows that the produced product is constantly changing. The product change is the resut of the market demands and readiness of production facilities and infrastructure in company. In 2014, the company started exporting coffee in the form of green beans to several countries. The export process is supported by the quality and quantity of coffee produced by PT Malabar. The Efforts made by the company to obtain a good quality of coffee is to maintain the quality of raw materials in the form of Chery bean for the consumer. The process of maintaining quality becomes a big challenge, since the raw material comes from coffee farmers. The process of knowledge transfer should be done by the company to coffee farmers becoming its partners as the effort to guarantee the coffee produced by them has a good quality.

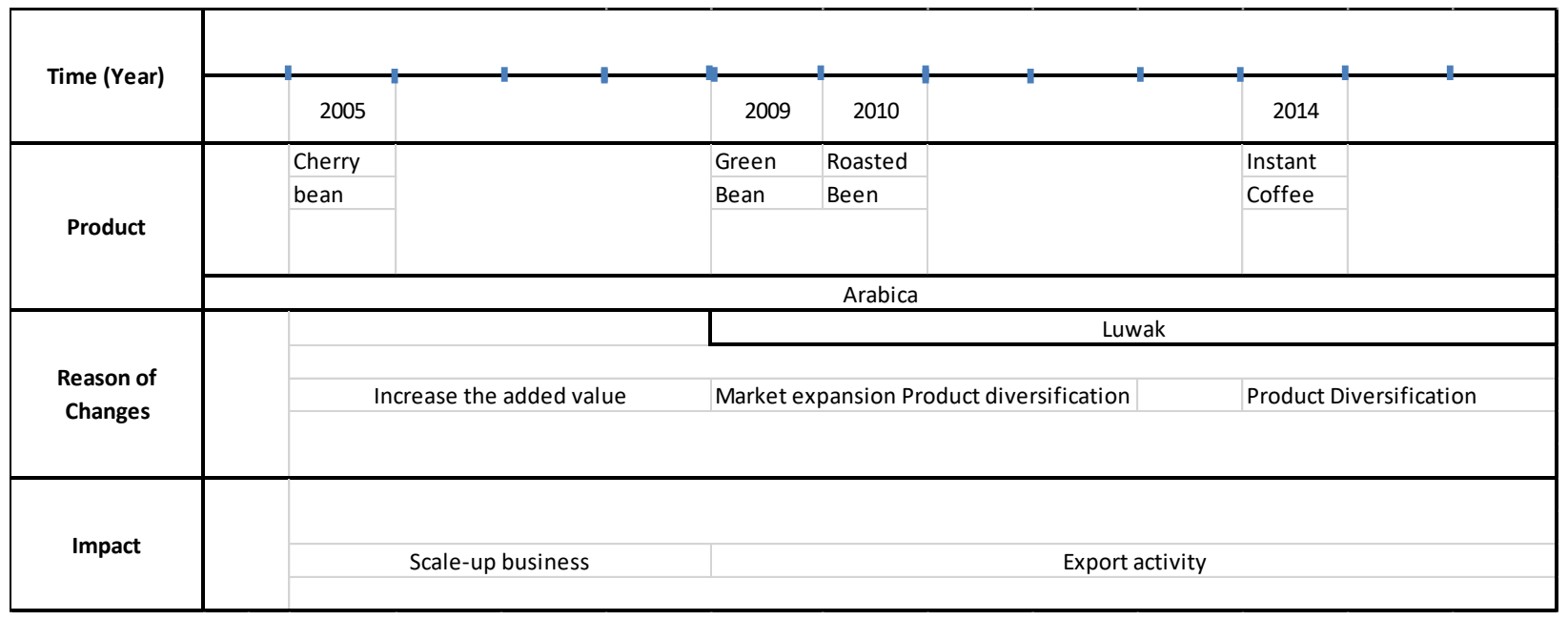

Figure 1: Historical Figure changing in product innovation

The process of product innovation occurs due to the company has a target to meet the market demand and increase the added value of its products. The process of diffusion and adoption occurs in realtion to the market demand trends and the experiment process conducted independently by the company. The process of product innovation will also affect the production process. In a coffee industry, the type of product will be produced from different types of processes. Furthermore, The Changes in process will affect the changes in technology used. Finally, product changes will affect other sub systems in coffee production system.

\section{Process Change}

Process Changes are related to the innovation in the production process. This process will have a direct impact on the type of coffee product produced. Within 12 years, the company has experienced various innovations. Hereby, the historical process of innovation in the production process: 


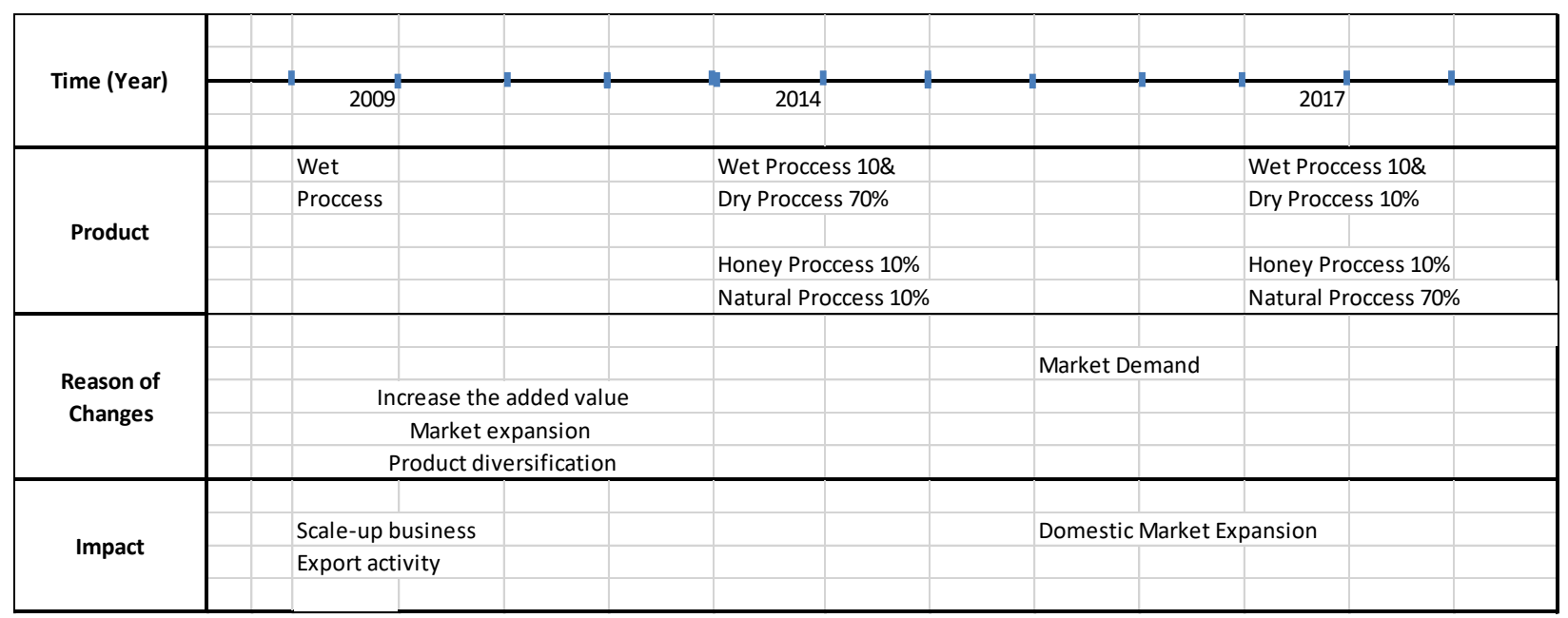

Figure 2. Historical process in Process Change

Changes in the production process are related to company's decision in determining the focus of products produced based on the consideration of opportunities and market demand. At the beginning of 2009, when Malabar Indonesia coffee processing unit started processing from cherry bean to green bean, the coffee product is produced in wet process. It is based on the preferences of domestic market that tend to the wet coffee type. The company had focused on domestic market in 2009. In 2014, the Company started producing various types of coffee, i.e. about $10 \%$ of wet process , $70 \%$ of dry process, $10 \%$ of Honey process, and $10 \%$ of natural process. Dry process percentage is greater than other types of coffee. It is indicated by the export activity. The company began to export coffee to several countries. International market demand of coffee type by dry process was very high. Another 30\% of coffee is produced for domestic market. Although the percentage of the amount of coffee produced for domestic market has decreased if compared to 2009, the amount is not reduced. This is due to the quantity of coffee production as a whole has increased significantly in 2014.

The changes of production process can be illustrated in the following diagram : 
Outside System

\begin{tabular}{|l|}
\hline Market \\
\hline Market demand \\
\hline $\begin{array}{l}\text { Raw material } \\
\text { potency }\end{array}$ \\
\hline
\end{tabular}

Inside System

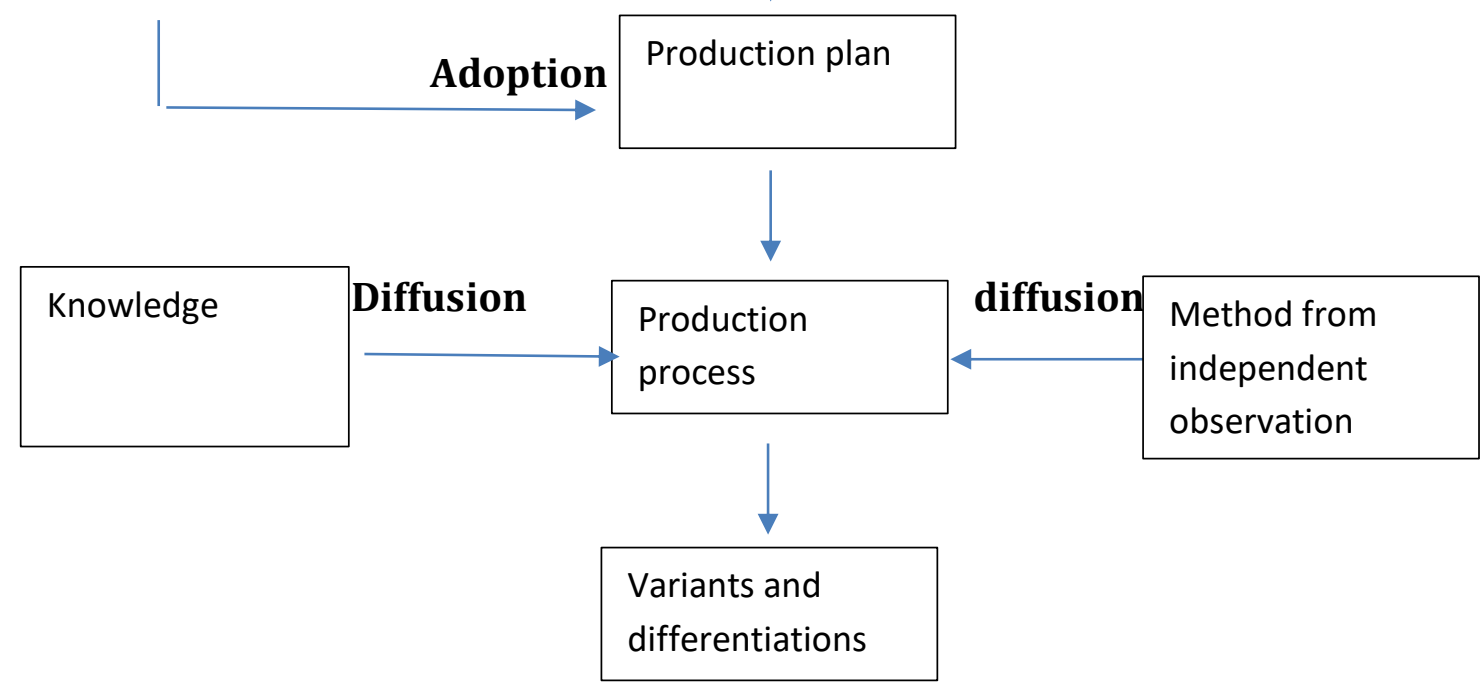

Figure 3. Innovation in process changes

The Process change diagram above shows that the initial consideration in the innovation is market opportunity, market demand, and the potential of raw materials that can be processed. Those three external factors are adopted by the company as the consideration for product planning activity. The products planned to be produced will have an impact on the process that will be performed. In term of conducting the production process, the company performs the process of diffusion from both the outside and inside. From the outside, the new method or knowledge is associated with the production process while from the inside, the system is related to the results of independent trials conducted. The method applied always refers to the condition of resources owned by the company.

\section{Technological changes}

The process of technological change are following the changes in processes and products produced. The historical changes that occur are as follows: 


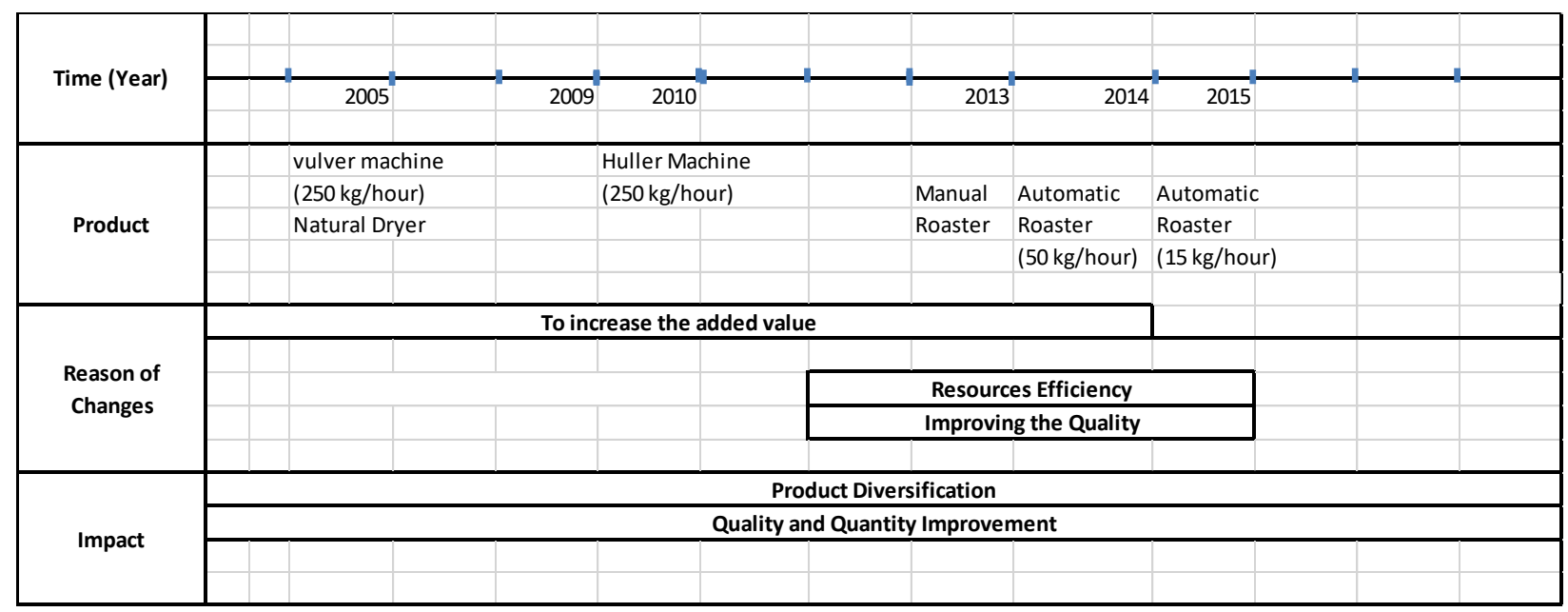

Figure 4. Historical changes of Technology Change

Technological changes related to the innovation process for generating the quality and quantity of products. In PT Malabar Kopi Indonesia, Technological change is done gradually. It is also depend on the company's ability to provide the necessary advice and infrastructure. In
2014, the Company export products for the first time. A fundamental change is evident from the use of technology by increasing the production capacity of the equipment used. Technology adoption causes the company's ability to provide market demand.
Outside system

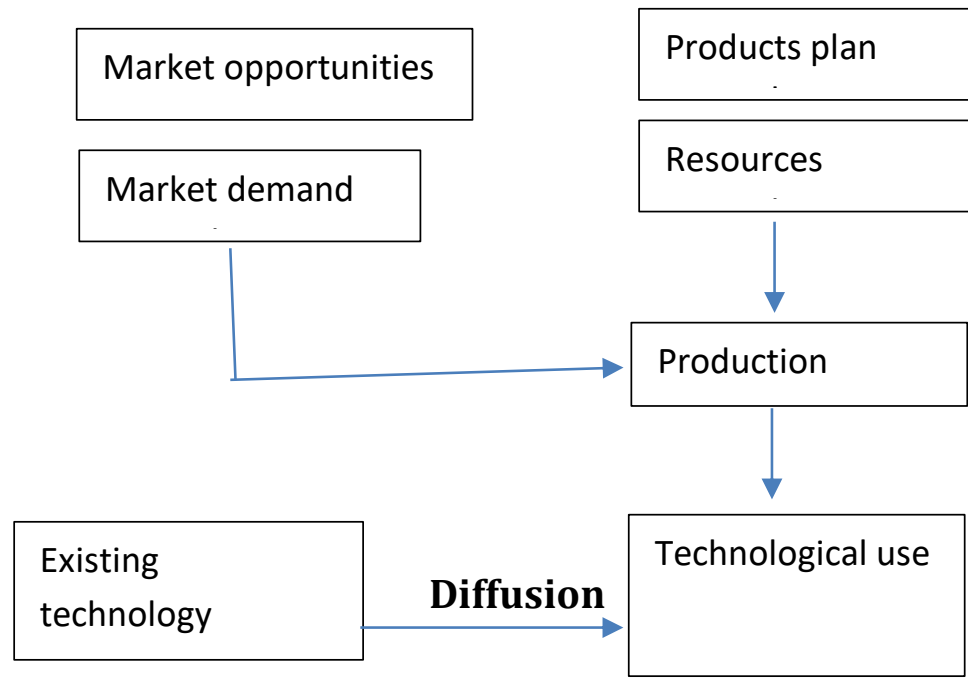

Inside company system

\begin{tabular}{l|l} 
diffusion & $\begin{array}{l}\text { New technology used by } \\
\text { the experiment }\end{array}$
\end{tabular}

Figure. Innovation in Technology Changes 


\section{Organization Changes}

PT Malabar also experienced a change in the form of corporate organization in its business process. When it was established in 2005, PT Malabar is a coffee business unit with small scale business. As The demand is increased by the time, and raw material opportunities can be processed also developed, the business unit morphed into CV. This is done in order to be able to expand the partnership network. A successful partnership is established with the coffee exporter. In 2014 in line with the company's desire to conduct the export process independently without an intermediary buyer, then the company metamorphosed into a limited liability company (PT). The changes that occur have an impact on the networking opportunity and develop a broader business. Here is the historical change of business form.

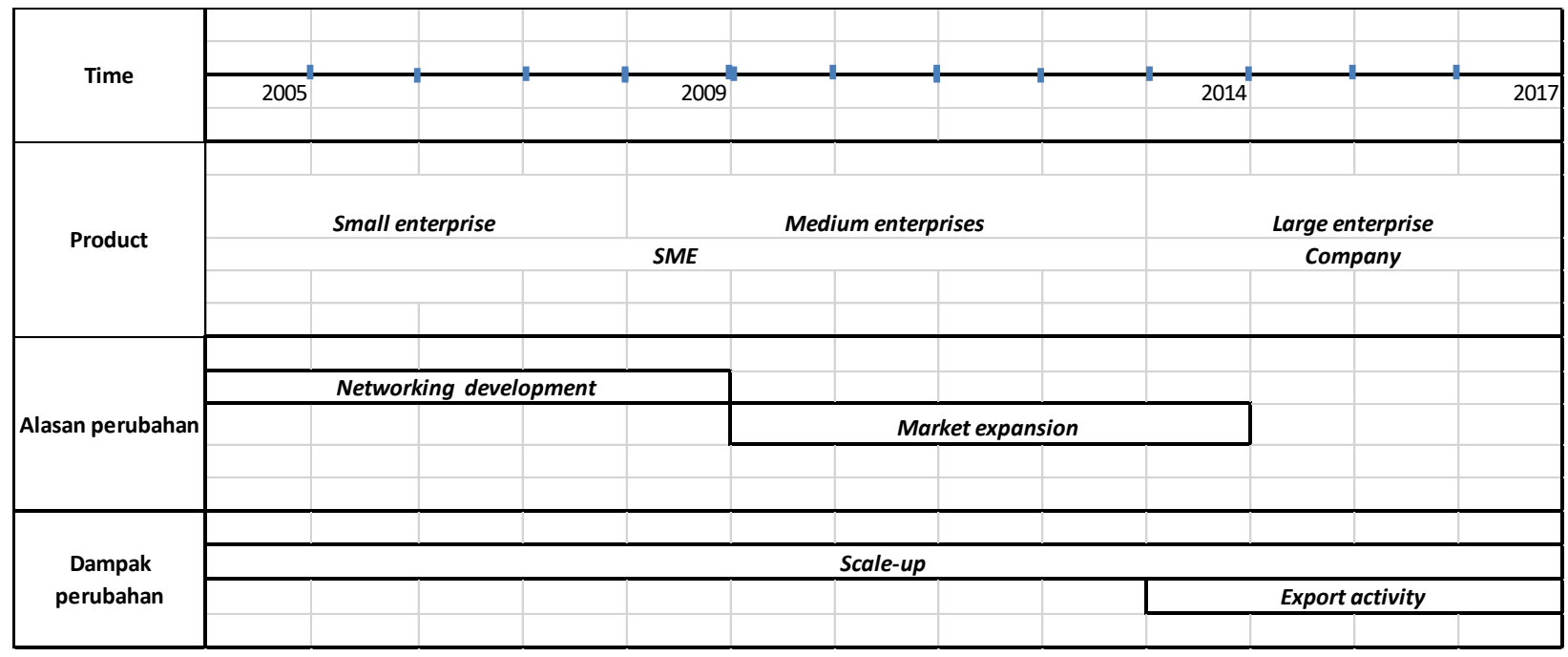

Figure 5. Historical process of Organization Changes

The innovation process on Organization Changes as follows:

Outside system Inside system

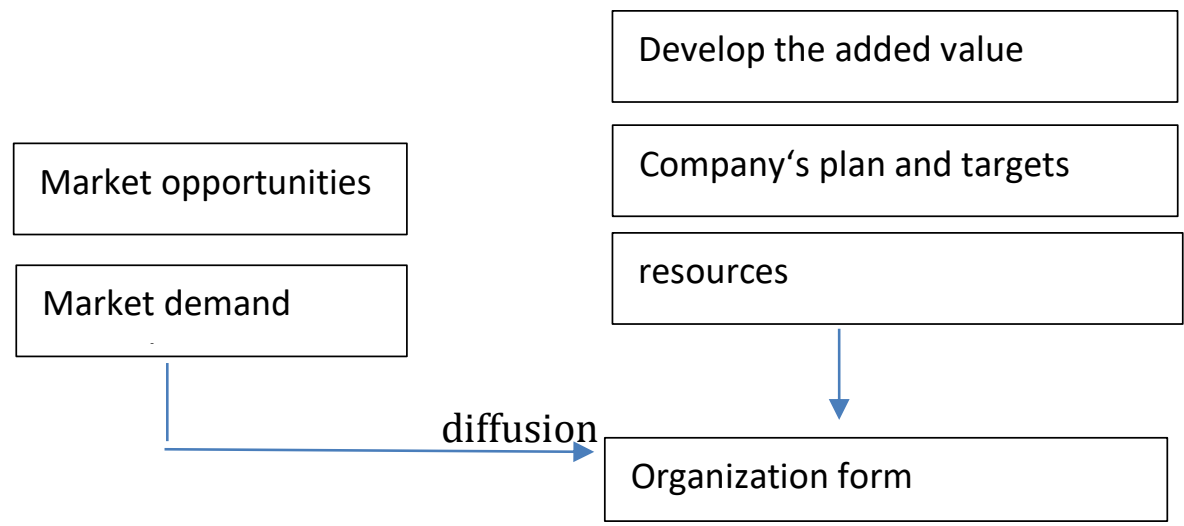




\section{Conclusion}

1. The result shows that the innovation process conducted by PT Malabar is divided into 4 terms, namely product innovation, process innovation, technological innovation, and organizational innovation.

2. Product changes occurs due to the company's desire to meet the market demand and increasing The value-added of products. The diffusion and adoption process occurs in association with the market demand trends and the experimental process conducted independently by the company.

3. Process changes is closely related to the type of product to be produced. The innovation process takes place within the method resulted by the independent observation and diffusion of the existing method from the outside company.

4. Technological changes related to the innovation process for generating the quality and quantity of products. The innovation process occurs in discovering and designing the technology used by independent observation and adoption of existing technology.

5. Organization Changes, conducted by considering market opportunities and business network expansion. Organizational change is also occurred in the management of supporting resources organizations such as farmer groups. Starting from Pagyuban forest management community into Forest Farmer Group and Cooperative Business Unit. Changes in the form of supporting organizations are conducted by consideration of maintaining relationships with supplier farmers and expanding opportunities for farmers' members to access the various supporting facilities of the coffee cultivation activity.

\section{References}

[1] Alia bihjajihant Raya. 2015. The performance of farmer groups in Yogyakarta Region, Indonesia: Organization Structure and Behavior and the Role of Leadership

[2] Mason, D., Bishop, K., \& Robinson, C. 2009. Business Growth and Innovation. NESTA. Research report. UK.

[3] Ministry of Agriculture RI. 2014. Data Komoditas Perkebunan.

[4] S.Wyche, P. Sengers, and R. E. Grinter. Hystorical.2006. Analysis : Using The Past To design Future. P.Dourish and A. Friday (Eds) : Ubicomp 2006, LNCS 4206. Pp 35-51, 2006. Springer-verlag Berlin Heiderberg 